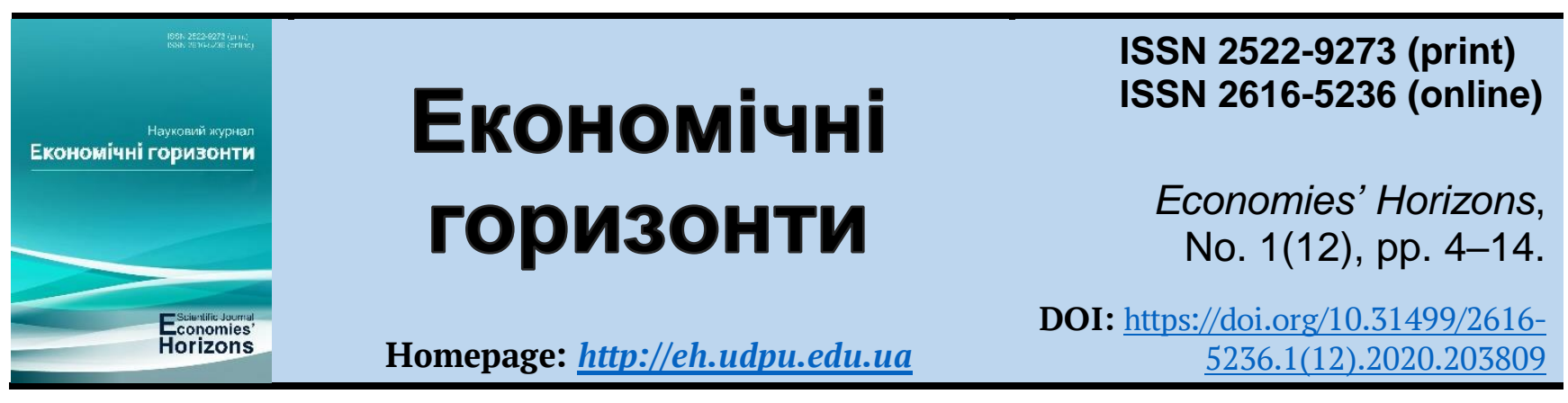

UDC 657:330.341.1:004.4

\title{
Modern innovative technologies in warehouse inventory management
}

\author{
Liliia O. Khodakivska ${ }^{1}$, Cand. Ec. Sc., Associate Professor \\ Yuliia M. Hrybovska², Cand. Ec. Sc., Associate Professor \\ Zhanna A. Kononenko ${ }^{3}$, Cand. Ec. Sc., Associate Professor
}

Received: 20 January 2020

Accepted: 25 February 2020
Khodakivska, L. O., Hrybovska, Yu. M. and Kononenko, Zh. A. (2020), "Modern innovative technologies in warehouse inventory management", Economies' Horizons, no. 1(12), pp. 4-14, doi: https://doi.org/10.31499/2616-5236.1(12).2020.203809.

Abstract. The purpose of the research is to study the benefits and potential problems of using Radio Frequency Identification Devices (RFID) in the warehouse management and inventory supplychain management. Methodology. In the process of writing this article a few various types of the observation, timing, motional, inventory, and historical methods (describing present time limitations of the current inventory tracking system compare to the benefits and obstacles of the proposed new generation inventory management system) were used. To support our conclusion, we used data from the sampling research conducting on the premises of six distribution centers. Generalized results of this study helped us to create a comparison between deployment of the system with the use of just RFID tags, just barcodes, and a hybrid technology, were both types of the inventory markings were incorporated. Results. As it was predicted even before the research begins, the result of the study proved that use of the RFID technology significantly improved reliability of the inventory system by reducing number of out-ofstock (OOS) items, improved speed of the data collection and reduce amount and time of the manual work. It was also determined that RFID technology will help companies to better manage day-to-day inventory operations. The overall results suggested that use of the RFID technology will help companies to reduce fixed and variable costs associated with the daily operation of the inventory management system. However, it was also found that RFID system is not prone to the problems related to the breakage of the equipment and tags themselves. It is also worth to take into account a cost of RFID tags compares to the barcodes or two-dimensional barcodes. If a medium size company will decide to switch to the RFID technology completely, the cost of the switch might not overweight the saving the company will have. In this case a possible solution might be two-dimensional barcodes. Practical meaning. We hope that results of the study, our observations, and comments will help businesses to evaluate deployment of the RFID technology better, understand some unrecognized pro and cons of it and find possible ways to improve on the current systems by using advantages of multiple inventory solutions.

\footnotetext{
${ }^{1}$ Poltava State Agrarian Academy; Associate Professor at the Department of Accounting and Economic Control; ORCID ID: https://orcid.org/0000-0002-6758-697X; e-mail: hodak katya@hotmail.com.

${ }^{2}$ Poltava State Agrarian Academy; Associate Professor at the Department of Accounting and Economic Control; ORCID ID: https://orcid.org/0000-0001-5205-9045; e-mail: julijal@ukr.net.

${ }^{3}$ Poltava State Agrarian Academy; Associate Professor at the Department of Economic Theory and Economic Research; ORCID ID: https://orcid.org/0000-0003-0074-8249; e-mail: konon_ukr@ukr.net.
} 
Prospects for further research. Consideration should be given to a possible research of the security of the RFID technology, safety of the protocols it uses to collect and transmit data, and, finally, a possibility of the external intrusion and malicious data manipulations and the ways to prevent it.

Keywords: RFID, single-dimensional barcodes, RFID vs. barcodes reading test, RFID vs. barcode security, RFID and out of stock inventory (OOS).

JEL Classification: O 32, M 41

Number of references: 13; number of tables: 2; number of figures: 6; number of formulas: $\mathbf{0 .}$

\title{
Сучасні інноваційні технології в складському обліку
}

\author{
Лілія Олександрівна Ходаківська ${ }^{1}$, к. е. н., доцент \\ Юлія Миколаївна Грибовська ${ }^{2}$, к. е. н., доцент \\ Жанна Андріївна Кононенко ${ }^{3}$, к. е. н., доцент
}

Стаття надійшла: 20.01.2020

Стаття прийнята: 25.02.2020
Khodakivska L. O., Hrybovska Yu. M., Kononenko Zh. A. Modern innovative technologies in warehouse inventory management. Економічні горизонти. 2020. № 1(12). C. 4-14. DOI: 10.31499/2616-5236.1(12).2020.203809.

Анотація. Мета дослідження - вивчити переваги і потенційні проблеми використання пристроїв радіочастотної ідентифікації (RFID) в управлінні складом і ланцюжком поставок. $M e-$ тодологія. У процесі написання цієї статті були використані кілька різних типів наглядових, тимчасових, рухових, інвентарних й історичних методів, що описують нинішні тимчасові обмеження поточної системи інвентаризації, в порівнянні з перевагами і перешкодами пропонованої системи управління запасами нового покоління. Щоб підтвердити наш висновок, ми використовували дані вибіркового дослідження, проведеного в шести розподільних центрах. Узагальнені результати цього дослідження допомогли нам провести порівняння між розгортанням системи з використанням тільки міток RFID, просто штрих-кодів й гібридної технології, де були включені обидва типи маркування товарів. Результати. Як і було передбачено ще до початку дослідження, результат довів, що використання технології RFID значно підвищило надійність системи інвентаризації за рахунок скорочення кількості товарів, відсутніх на складі, підвищення швидкості збору даних, зменшення кількості і часу ручної роботи. Загальний результат показав, що використання технології RFID допоможе компаніям скоротити постійні та змінні витрати, пов'язані зі щоденною роботою системи управління запасами. Однак, ще було встановлено, що система RFID також схильна до проблем, пов'язаних з поломкою обладнання та самих бирок. Практичне значення. Ми сподіваємося, що результати дослідження, наші спостереження і коментарі допоможуть компаніям краще оцінити розгортання технології RFID, зрозуміти деякі недостатньо висвітлені їі переваги і недоліки, знайти можливі шляхи поліпшення існуючих систем з використанням переваг декількох рішень для інвентаризації. Перспективи подальших досліджень. Слід розглянути можливе дослідження безпеки технології RFID, безпеки протоколів, які вона використовує для збору і передачі даних, i, нарешті, можливість зовнішнього вторгнення і зловмисних маніпуляцій з даними та способи їх запобігання.

\footnotetext{
${ }^{1}$ Poltava State Agrarian Academy; Associate Professor at the Department of Accounting and Economic Control; ORCID ID: https://orcid.org/0000-0002-6758-697X; e-mail: hodak katya@hotmail.com.

${ }^{2}$ Poltava State Agrarian Academy; Associate Professor at the Department of Accounting and Economic Control; ORCID ID: https://orcid.org/0000-0001-5205-9045; e-mail: julijal@ukr.net.

${ }^{3}$ Poltava State Agrarian Academy; Associate Professor at the Department of Economic Theory and Economic Research; ORCID ID: https://orcid.org/0000-0003-0074-8249; e-mail: konon ukr@ukr.net.
} 
Ключові слова: RFID, одномірні штрих-коди, тест швидкості зчитування RFID і штрихкоди, захист RFID і штрих-коду, RFID і відсутність товарів на складі (OOS).

Кількість джерел: 13; кількість таблиць: 2; кількість рисунків: 6; кількість формул: 0.

\section{Introduction.}

In the past decade an effective and efficient warehouse management system is a topic for discussion in most of the medium and large companies around the world. How this system will be implemented and fit into the company's domestic and global supply chain infrastructures will decide the business outcome and make or break the company future. There are a few moving parts in this equation. First of all, we need to determine the primary warehouse functions and tasks that make the process work as one mechanism.

Warehouse Operational Tasks (WOT):

- Warehouse layout: One of the most crucial tasks in the warehouse operation is to store inventory in the way that will allow its fast movement, with minimal time on searching, and negligent possibility of selecting the wrong item.

- Receiving processes: Orderly receiving and inventory of the incoming items.

- Picking process: Easy and timely efficient mechanism of finding necessary items ordered, that will minimize number of errors.

- Packing process: Will prepare the shipment according to required safety standards and supply necessary paperwork.

- Shipping process: Ship the order in the appropriate time frame, with the correct shipper, with ordered delivery speed, and with the necessary tracking mechanism.

- Return process: Inspect and inventory the returned items according to the company policies and within the timeframe written in the policy. Return paperwork should also be generated and send to the customer (Gruend and Gorsten, 2017; Hardgrave and Waller, 2005; IMPIMJ, n.d.).

The second part of the equation is the system that monitor and manage the warehouse operations.
Inventory Management System (IMS).

A IMS will enable the companies to analyze current warehouse procedures and performance, and implement possible improvement that will help:

- Inventory control optimization: Finding a right balance between having too much inventory on hand with a possibility to have some items out of stock (OOS).

- Rationalization of the use of existing warehouse space: Based on the type of the inventory and type of the operations the company gets involved, the system might suggest the optimal ratio between floor storage compare to the vertical storage; type of inventory packaging (bulk storage vs individual items); and provide the most efficient location of the items based on the selling/ordering pattern.

- Improve worker productivity: By optimizing the layout of the warehouse and equipping workers with the necessary tools and digital means of dealing with the IMS system; providing adequate training (including safety training) the company will be able to save on the labor cost as well as any other cost associated with the misplaced or lost inventory and avoidable cases of the wrong shipped items (Gruend and Gorsten, 2017; Hardgrave and Waller, 2005; IMPIMJ, n.d.; McBeath, 2018).

So, what can effectively connect WOT and IMS? We would place that on the ability of the warehouse personal to locate, move, and ship the right inventory, in the correct quality, to the designated customer, in the shortest amount of time. The way how this system does it today is by labeling merchandised with the barcodes. This technology is almost 46 years old now and, despite the fact of its cheap cost and wide adoption, might no longer fits criteria for the preferable solution in the future, due to its substantial limitations. However, a new breed of the inventory technology hits the 
market about 15 years ago and finally reached the point where its adoption can be cost effective on the mass market (for the right size of the companies and operations). The name of this technology is Radio-Frequency Identification (RFID) (AdvancedMobileGroup, 2014).

RFID can be translated as small electronic device that contains a data chip and antenna. On average the chip can hold up to 2000 bytes of information. Like other identification data sources (barcodes for example), the RFID device provides a unique identifier of the object it represents, and that ID can be retrieved by the specialized scanner. The scanner sends out a radio frequency signal and that flow provides necessary mean for a tag to communicate back, by using energy supplied by a signal. That type of RFID tag gets called passive. There are other types of RFID tags in existence, but we would not cover them for this article because a very few of them are in use in the warehouse management system. When RFID tag gets inside the area covered by the scanner, it recognizes the activation signal emitted by the antenna. That activates the RFID chip and allow information stored on the tag's chip to be send back to the scanning device. One of the main advantages of the RFID environment is an ability to place the actual RFID chip anywhere on or inside the inventory object. It does not need to be on the surface (as with the barcode). The scanner will be able to read information stored on the chip in less than 100 milliseconds. Such type of speed allows simultaneous read of multiple tags located within vicinity of the reader.

\section{Literature review.}

In most of the recent publications the authors emphasize different benefits of the RFID technology (Table 1).

\section{Table 1. Benefits of the FRID technology}

\begin{tabular}{|l|l|}
\hline RFID Benefit Type & \multicolumn{1}{|c|}{ Description } \\
\hline Data Collection & $\begin{array}{l}\text { RFID system is able to collect data automatically and simultaneously from } \\
\text { different locations. Data collection can be separated by product, activity or } \\
\text { location. That significantly saves amount of the manual labor. }\end{array}$ \\
\hline $\begin{array}{l}\text { Quality of the } \\
\text { Captured Data }\end{array}$ & $\begin{array}{l}\text { RFID data collection mechanism allows reporting based on the desired seg- } \\
\text { ment of the inventory (like low on stock or most shipped items). Also, the } \\
\text { speed of the data collection and correctness of the reporting significantly re- } \\
\text { duces inventory discrepancies and OOS items. }\end{array}$ \\
\hline $\begin{array}{l}\text { Inventory Error } \\
\text { Reduction }\end{array}$ & $\begin{array}{l}\text { With the ability to correctly identify multiple items on the distance, the RFID } \\
\text { technology provides better picking information to the warehouse personnel, } \\
\text { reduces the number of incorrect shipments and, as a result of that, reduces } \\
\text { number of returns. All of that reduces the company operational cost and } \\
\text { shorten orders fulfilment time. }\end{array}$ \\
\hline Data Availability & $\begin{array}{l}\text { Since RFID data collection happens in real time and can cover significant } \\
\text { areas with just one scan, the inventory information can be presented to the } \\
\text { IMS system in real time as well. That benefit makes planning and operation } \\
\text { management a lot easier. }\end{array}$ \\
\hline $\begin{array}{l}\text { Lower Cost and } \\
\text { Improve } \\
\text { Productivity }\end{array}$ & $\begin{array}{l}\text { Due to the nature of RFID data collection and automation around it, RFID } \\
\text { allows IMS to track, locate, and move inventory around the supply chain } \\
\text { more quickly. By increasing processing speed and decreasing number of } \\
\text { manual labor hours required by the older technologies. All of that led to the } \\
\text { cost saving and improved productivity across the enterprise. }\end{array}$ \\
\hline
\end{tabular}

Source: formed on the basis of the AdvancedMobileGroup (2016) and CoreRFID (2019).

However, it would be worth to mention an older technology that gained world-wide adoption a long time before the RFID and compare pro and cons of each of them. The Table 2 below summarizes most of the observations reviewed for this article. 
Table 2. RFID and Barcodes Compare and Contrast

\begin{tabular}{|l|l|l|}
\hline \multicolumn{1}{|c|}{ Statistical Data On } & \multicolumn{1}{c|}{ RFID } & \multicolumn{1}{c|}{ Barcode } \\
\hline Communication channels & Radio signals & Optical scanner \\
\hline Scanner read coverage & Up to 20 $\mathrm{m}$ & Up to $25 \mathrm{~cm}$ \\
\hline Simultaneous read rate & Many & One \\
\hline Data on the tag & Can be updated & Cannot be updated \\
\hline Size of the data on the tag & Up to 2000 char & Up to 25 char \\
\hline Location of the tag & Anywhere on or inside the package & On the surface of the package \\
\hline Scanning data & Can identify the item itself & Can identify the type of the item only \\
\hline Item tracking & $\begin{array}{l}\text { Can be done automatically through } \\
\text { the whole distribution channel }\end{array}$ & $\begin{array}{l}\text { Requires human intervention and } \\
\text { manual labor }\end{array}$ \\
\hline Industry wide standards & No & Yes \\
\hline Time and labor to setup a system & Significant & Minimal \\
\hline Cost of the tag & Up to 7-10 cents or more per piece & $>1$ cent \\
\hline $\begin{array}{l}\text { Resistance to jamming or } \\
\text { distortion }\end{array}$ & Somewhat & Non-existing \\
\hline Employees training cost & Moderate & Small \\
\hline Data Security & Needs to be improved & n/d \\
\hline
\end{tabular}

Source: formed on the basis of the Redbeam (2019); Pontius (2020); QuestSolution (2020).

\section{Methods.}

As we analyzed different published materials about RFID implementation, one common thesis was very visible across all of the publication: RFID technology will deliver a significant cost reduction for the business and reduce OOS items compare to the barcode technology. However, some studies are also showing that RFID systems might not as reliable and accurate in the difficult environments as we would like to think. To make unbiased comparison of both technologies, the study was conducted on the premises of a single supermarket chain. The following are the primary objectives of the study.

Organization of the Studies. In order to keep research data confidential and not to reveal a company used in this review (due to the privacy issues), the authors will refer to it as a company XYZ. This company currently operates a large network of warehouses, distribution centers, and supermarkets across the United States. The chain sells more than $\$ 5.5$ billion of inventory during the fiscal year. As part of the study the company decided to investigate a possibility to replace the existing traditional single-dimensional barcode system. A total of six distribution centers, inside two separate (but closely located) geographical urban areas, were identified. All of the distribution centers stock similar product inventory items and during the past fiscal year fulfilled roughly the same number of work orders $(+/-$ $15 \%$ difference). This group was divided into two subgroups: Test and Control (with three distribution centers in each group). To keep the cost of the study down time: time, motion, and inventory studies were performed on the 460 uniquely identified product types that have both: enabled RFID tags and barcodes. Each of the selected products was classified as a medium speed moving/selling item. Only passive RFID tags and mobile readers had been used in the trail in the Test group. In each of the distribution centers in the Test category, a group of 8 employees was trained to operate both RFID and barcode scanners.

Measurement and Sampling. The measurements were taking 5 days a week (Tuesday - Saturday) in order to provide a consistent picture of the available inventory and reduce possible fluctuations related to the day of week. The time period of the sampling was averaged between 10 in the morning and 3 in the afternoon. Inventory level of each of the product types identified for the study was measured once per scan period. During that time all operators were measured on the speed and 
accuracy using software package that incorporated closed circuit security cameras, artificial intelligence (AI) mechanism, and database datamining tool. This approach allows the trial to be performed in the very precise way and with minimal amount of extra manual labor. The trial was set in three sub sequentially cycles lasted six weeks each. During the first cycle, all six storage facilities used barcodes on the selected products. In the second cycle, three distribution centers in the Test group enabled RFID on the 230 product types. And during the last cycle, all 460 products were RFID enabled. Tags were used by the employees working in the distribution centers that belong to the Test group in the scanning process. The control group of the other three distribution centers continued to use barcode scanning only.
4. Research objectives.

a) Does RFID system over perform the standard barcode system?

b) Can the RFID technology significantly reduce the number of OOS items?

c) Will the RFID technology allow great speed and accuracy compare to the barcodes?

d) What is the reliability of the RFID tags and scanners compare to the existing barcode labels and scanners and what potential problems this technology can be exposed to?

\section{Results and discussions.}

a) Inventory level with the use of the RFID technology and without.

The data represented in the Figure 1 and Figure 2 clearly shows a reduction in the OOS items in the Test group with implementation of the RFID technology.

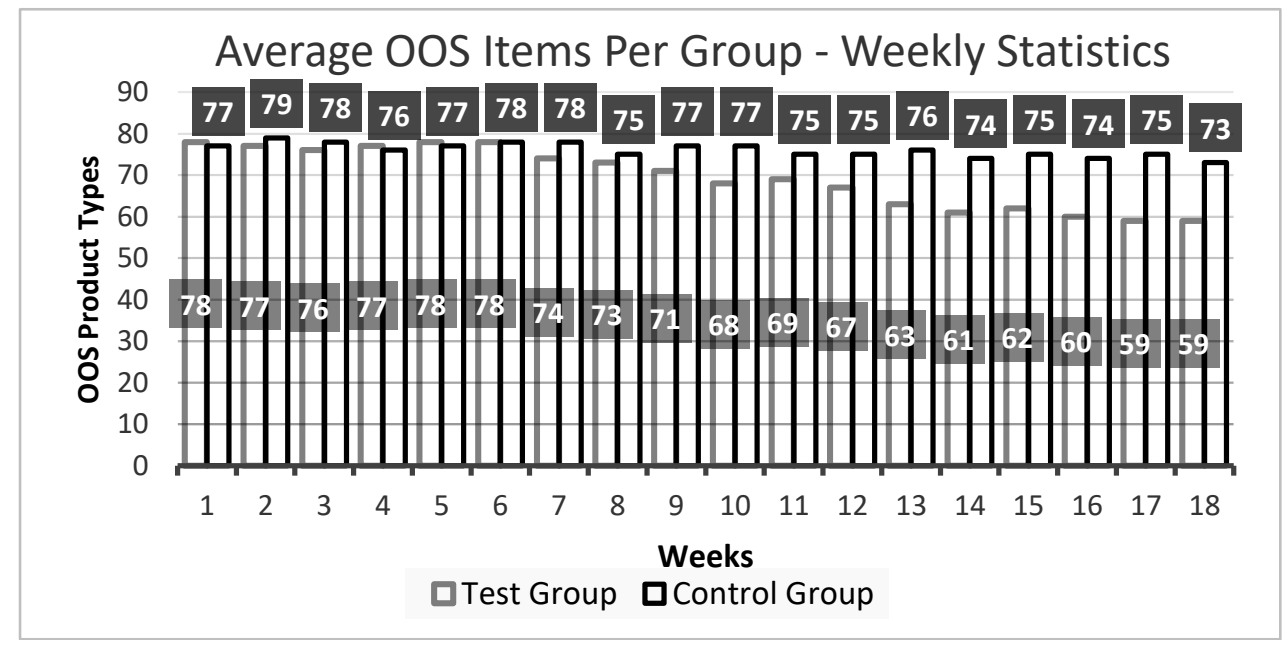

Fig. 1. Average OOS Items Per Group - Statistics

Source: author's own developments.

With two groups starting almost on the same level with 78 and 77 OOS items respectfully, we see this number drops to 67 in the Test group (14,1\% reduction) with half of the items using RFID and to 59 with entire population of the sampling product types using RFID (24,3\% reduction). However, it also worth to mention a slight reduction of the OOS items in the control group as well. That reduction was from 77 to 73 (5,2\% reduction). The diminishing of the OOS in the control group (where RFID technology was not implemented) can be attributed to a few factors: continues observation of the day-to-day product levels and better understanding of the inventory needs during the pick times by the company inventory system; changes in supply and demand patterns of the specific seasonal items and etc. But that reduction in the control group should be accounted in the reduction of the OOS items in the Test group. So, the overall level of OOS items decreased in the Test group should be calculated as $24,3-5,2=19,1 \%$. That is still a very impressive number.

b) Speed of the scanning operation.

The information presented in the Figure 3 and Figure 4 shows the difference in scanning speed between RFID and barcodes. 


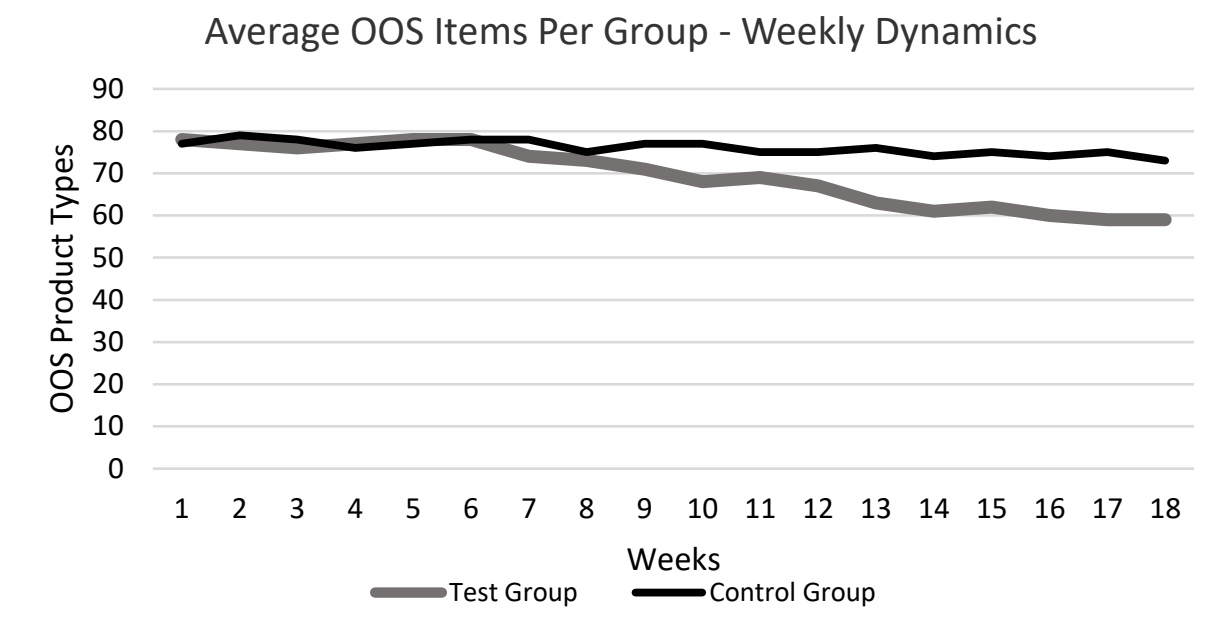

Fig. 2. Average OOS Items Per Group - Dynamics

Source: author's own developments.
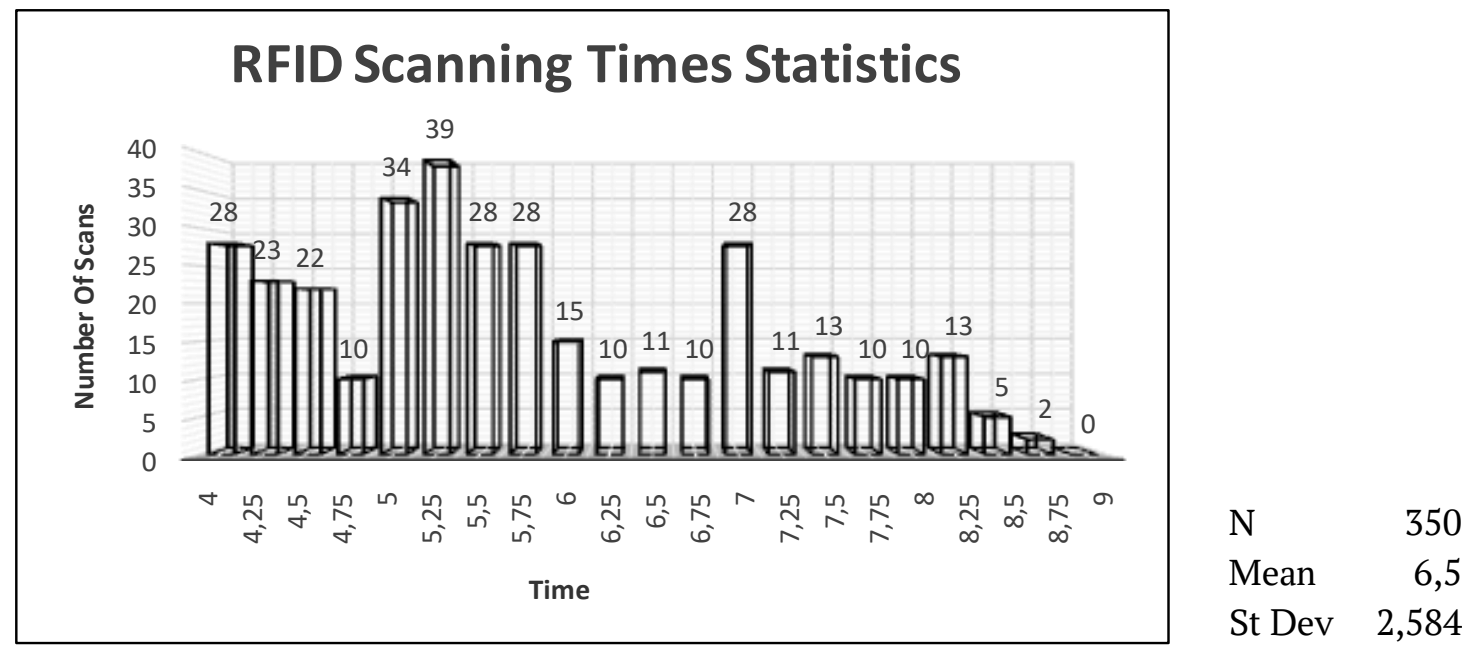

Fig. 3. FRID Scanning Tags Statistics

Source: author's own developments.

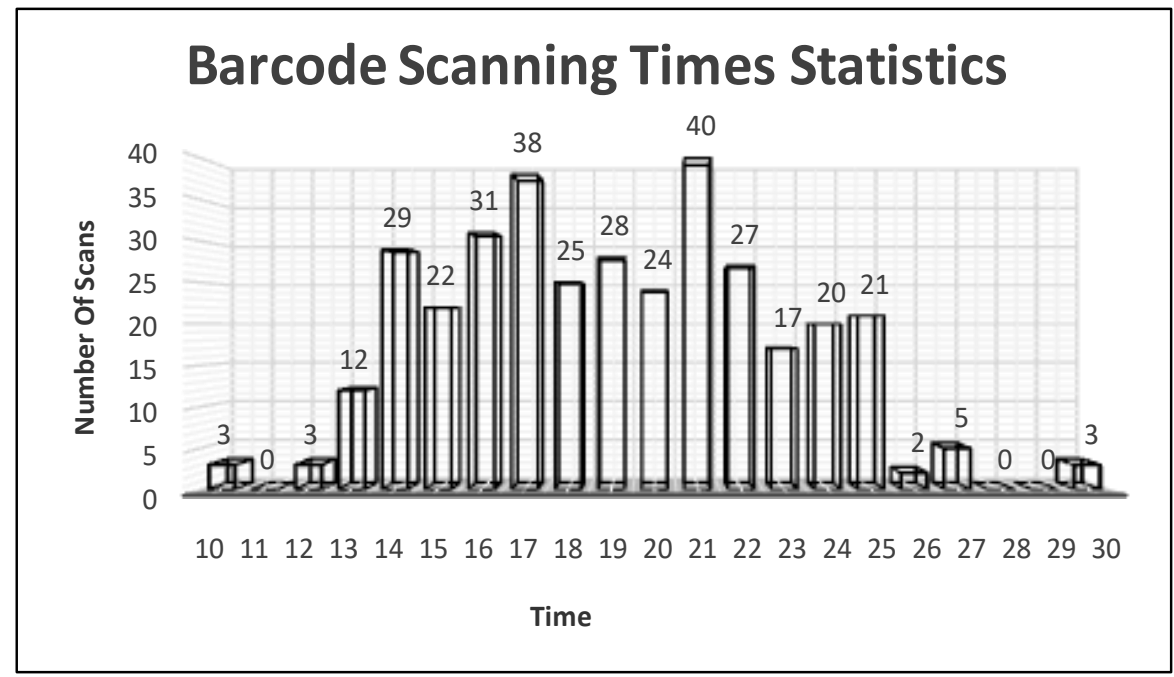

$\mathrm{N}$

Mean $\quad 16,83$

St Dev 3,1258

Fig. 4. Barcode Scanning Statistics

Source: author's own developments. 
The data confirms our initial assumption of the greater benefit the RFID technology can bring to the company attempt of reducing the fix cost (in this case the most expensive part of it: manual labor). The observation shows that average/mean scan time of the FRID tag is approximately 6,54 seconds compare to the 16,83 seconds for the barcode. That is almost three times gain in speed. All of that combine shows that RFID mechanism can perform better, be more productive and efficient, and bring a substantial operation benefits to the company. However, it also worth to mention here that, based on the sampling data, RFID is less consistent over the period of time compare to the barcodes. The data shows that barcodes represent a wide scanning time range, with insignificant variations over a period of time, while average mean of the RFID vary more than of the barcode, but cycle time stays closer to the mean.

c) Equipment Problems and Data Error.

By analyzing the type of equipment failures and subsequent errors, we saw during the trial period, the following category of problems were generalized.

RFIDs (Figure 5):

- Unreadable or broken RFID tag.

- User errors due to the insufficient level of training or use incorrect use of the equipment.

- Incomplete scan of the tag that resulted in the equipment warning and additional scanning attempts or extra manual work. These events were due either to the tag density in the area, transponder sensitivity, signal absorption, or reflection and electrical noise and some others. In the chart below such type of events were classified as "Issues with RFID Scanners".

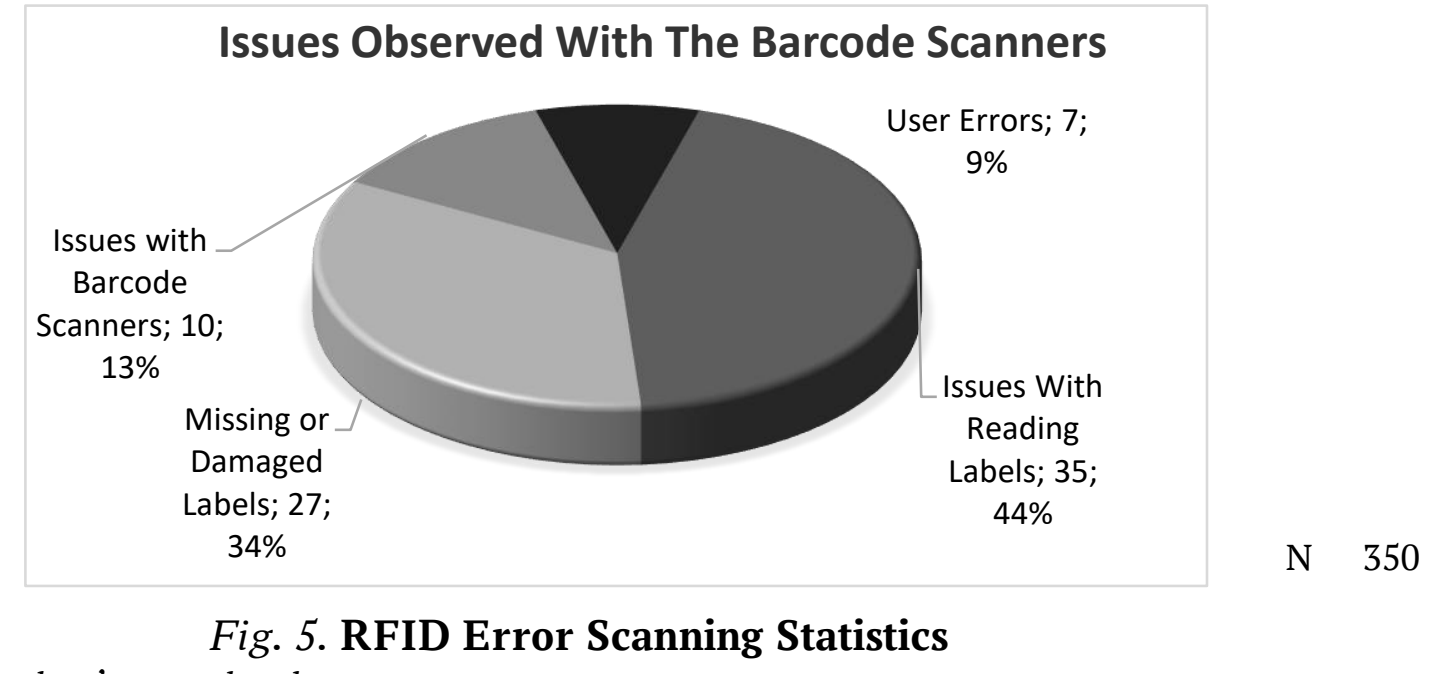

Source: author's own developments.

Barcodes (Figure 6):

- Missing or unreadable label outside of the package that requires additional manual operations by the employee.

- Non-working or incorrectly working barcode scanners.

- User errors resulted by mistaken identification of the item.

As we can see from the above observation, both technologies still have some room for improvements. They are not perfect. Each of them encounters a significant number of equipment failures and errors. The data shows that barcodes might experience up to $10 \%$ reading errors level while RFID technology has only $4 \%$ reading errors. However, at the same time, the RFID scanners might break on average in $6,5 \%$ of all scan attempts (compare to $3,5 \%$ for barcodes). That indicates that this technology is still in the developing phase and will require more improvements in the future. Finally, RFID operation tend to require more user training in order to reduce unintentional user mistakes. We saw increased number of 
the user errors using RFID equipment compare to the barcode readers $(8,2 \%$ vs $2 \%)$. As data shows, the user errors with the RFID equipment is more than 4 times more likely compare to the same user using barcode readers (that might be explained by the novelty of the RFID technology compare to the half of the century history of the barcodes).

\section{Issues Observed With The RFID Scanners}

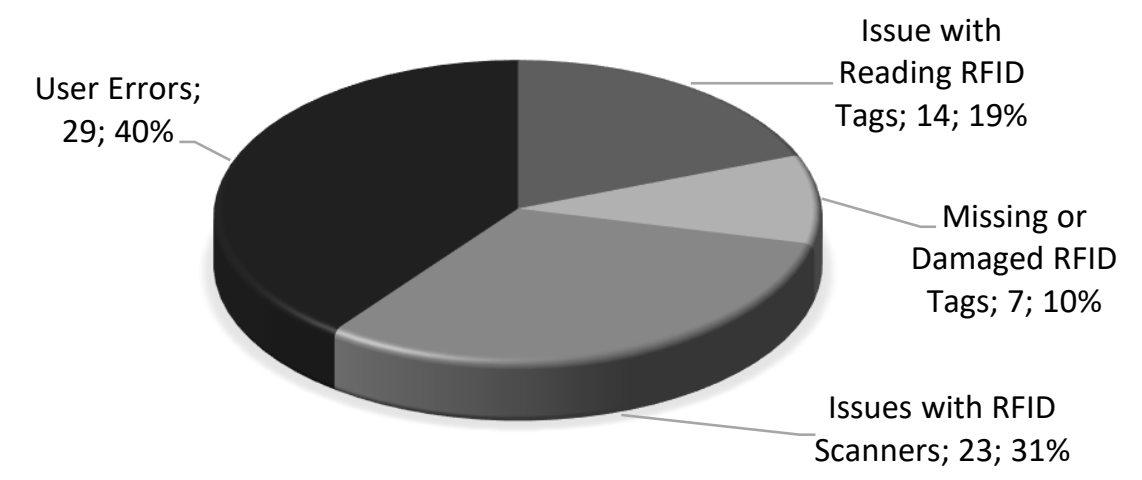

N 350

Fig. 6. Barcode Error Scanning Statistics

Source: author's own developments.

\section{Conclusions.}

As you can see in this study, the authors tried to provide a comprehensive analysis of the benefits and problems with incorporating RFID technology in the warehouse/supermarket environment. The results were as follow: RFID technology does overperform existing barcode system. The average reduction in the OOS items might be in the range of approximately 20\%. The RFID technology can also substantially increase the accuracy and operation speed of the inventory operations, all of the while reducing the amount of manual labor and decreasing operational cost. However, the novelty of the RFID technology plays a significant role on the number on the equipment failures (compare to the barcodes). The overall result of the study mostly supports the conclusions authors of other publication made: the greatest benefit of the RFID system is an ability to scan multiple items simultaneously and without being in the direct line of sight of the items. That immediately put RFID ahead of the barcodes in the industries where speed and quality is at most importance. The research also confirms the authors prediction that any new technology is not immune to the different types of the equipment failures (especially in the conditions that are not ideal and even harsh). These failures negatively affected variations in the mean of the scanning time period. The other observation is related to the remaining challenges any company, who consider implementing RFID, will face - employees training. The higher initial implementation cost of the system might be offset by the future reduction in the manual (unskilled) labor. Ability of the system to prevent (or warn) user errors might also indicate a new way to train employees. That potentially will serve as an attraction point to the potential adopters of the technology and provide another cost saving mechanism. However, there was one aspect that we did not cover in this research: two dimensional barcodes. That relatively new technology, that provides improved scanning speed, better reliability (compare to the single-dimensional barcodes), more space to store information on the label might, and importantly, keep the cost of the implementation and use down, might became a significant competitor to the RFID adoptions.

We also would like to address in more derails some issues we saw with problems RFID technology might poses. As noted by Derakhshan, the primary data management problems arising from its simplicity are lowlevel data, redundancy in output resulting in a 
data in-flood, and inaccuracy of readings. First, the only information generated from an RFID chip is in the format (Electronic Product Code, Location, Time). In order to be useful to suppliers, this must be transformed through various inferences into a real-time system. This creates the possibility for error when the data is not sufficient enough to understand where an item tagged by an RFID chip is located. For instance, if a reader failed to pick up a given item of inventory, the tracking system must make certain assumptions as to its whereabouts such as malfunction of readers or its theft along the way - this creates uncertainly derived information.

The unique recognition of RFID chips creates the second issue - unnecessary duplication of data through redundancy at the reader level and redundancy at the data level. In order to capture all chips within a given vicinity, readers must be placed with an overlapping range of each other. As a result, two readers often pick up the data from the same RFID tag. While this is a significant data collection problem in its own right, the snowball effect occurs due to the constant stream of data being transmitted to the readers. RFID data is in greater volume than other forms of data streams. As we saw in our tests, in some instances, readers perform over 100 readings of these chips per second. However, only the readings where the RFID's metrics are changing are useful for enterprise purpose. As a result, massive amount of server space is required to hold data that is almost entirely useless.

Finally, based on our research, one of the greatest issues preventing the ubiquity of
RFID tagging is the reliability of the data stream. "The observed read rate in real world RFID deployments is often in the $60-70 \%$ range" (Derakhshan, 2007). This is a function of the cheap and power-light design, as well as the wireless communication setup. However, the lack of individual accuracy is at least partially mitigated by the reader redundancy mentioned above and by the significance of temporal changes rather than individual recordings in applications.

Due to their simplicity, RFID tags also come with a collection of security issues. The simplest type of infiltration would be through RFID skimming, whereby a hacker with an external reader can read the tags without alerting the owners of the tag (Juels, 2006). Even tags that are protected through algorithms still broadcast a unique identifier that can provide the necessary information for physical tracking. This poses an even larger issue when this information is combined with personal data, allowing someone to, for instance, create a profile of an individual's purchases.

As a prospect for the further research, we should investigate RFID security and possible ways to infiltrate RFID system and manipulate with data. Example of such intrusion and manipulation could be an attacker listens to the network and records exchanges between tags and the reader or an attacker overloads a reader with a specific tag frequency requests, preventing the functioning of the reader. Although yet to be widely adopted, solutions to these concerns such as the delegation tree, protocol added schemes, tag killing, XOR encryption, and blocker tags have been proposed.

\section{References}

AdvancedMobileGroup (2014), “40\% Warehouse labor costs reductions with RFID," available at: https://www.advancedmobilegroup.com/blog/how-does-modern-rfid-technology-improve-warehouse-performance (Accessed 9 January 2020).

AdvancedMobileGroup (2016), "Why RFID tech in retail is so important", available at: https://www.advancedmobilegroup.com/blog/why-rfid-tech-in-retail-is-so-important (Accessed 9 January 2020).

Beqqal, M. E. and Azizi, M. (2017), "Review on security issues in RFID systems", Advances in Science, Technology and Engineering Systems Journal, vol. 2, no. 6, pp. 194-202. doi: http://dx.doi.org/10.25046/aj020624. 
CoreRFID (2019), “Benefits of RFID - Why do you need RFID solutions? How does it affect your business?”, available at: https://www.corerfid.com/rfid-technology/what-is-rfid/benefits-of-rfid/ (Accessed 9 January 2020).

Derakhshan, R., Orlowska, M. and Li, X. (2007), “RFID data management: challenges and opportunities”, IEEE International Conference on RFID Gaylord Texan Resort, Grapevine, TX, USA, March 26-28, pp. 175182.

Gruend, T. and Gorsten, D. (2017), A comprehensive guide to retail out-of-stock reduction in the fast-moving consumer goods industry, Procter \& Gamble Company, USA, 58 p., available at: https://www.nacds.org/wp-content/uploads/2017/02/Retail-Out-of-Stock-Reduction.pdf (Accessed 9 January 2020).

Hardgrave, B. C. and Waller, M. (2005), “Does RFID reduce out of stocks? A preliminary analysis”, available at: https://rfid.auburn.edu/papers/rfid-reduce-stocks-preliminary-analysis/ (Accessed 9 January 2020).

IMPIMJ (n.d.), "Various systems using RAIN RFID technology", available at: https://www.impinj.com/aboutrfid/types-of-rfid-systems (Accessed 9 January 2020).

Juels, A. (2006), "RFD security and privacy: a research survey", IEEE Journal on Selected Areas in Communications, vol. 24, no. 2, pp. 381-394.

McBeath, B. (2018), "The ROI for RFID technology in retail”, available at: https://losspreventionmedia.com/theroi-for-rfid-technology-in-retail/ (Accessed 9 January 2020).

Pontius, N. (2020), "What are RFID tags? Learn how RFID tags work, what they're used for, and some of the disadvantages of RFID technology", available at: https://www.camcode.com/asset-tags/what-are-rfid-tags/ (Accessed 9 January 2020).

QuestSolution (2020), "Pros and cons: The use of RFID for inventory management", available at: https://www.questsolution.com/blog/item/34-pros-and-cons-the-use-of-rfid-for-inventory-management (Accessed 9 January 2020).

Redbeam (2019), "What's the difference between barcode and RFID?", available at: http://www.redbeam.com/rfid-vs-barcode/ (Accessed 9 January 2020).

Цей твір ліцензовано на умовах Ліцензії Creative Commons «/з Зазначенням Авторства - Некомериійна 4.0 Міжнародна» (CC BY-NC 4.0).

This is an open access journal and all published articles are licensed under a Creative Commons "Attribution-NonCommercial 4.0 International" (CC BY-NC 4.0). 